ECOLOGICA, Vol. 28, No 102 (2021), 180-186

https://doi.org/10.18485/ecologica.2021.28.102.6

Originalni naučni rad

UDC: 628.4.046:502.13]:[616.98:578.834]

\title{
Problemi i izazovi u upravljanju medicinskim otpadom u vreme pandemije COVID-19
}

\section{Problems and challenges in medical waste management during the COVID-19 pandemic}

\author{
Anđelka Tripkovićc ${ }^{*}$, Ljiljana Arsić$^{2}$, Sanja Dobričanin ${ }^{3}$ \\ 1,2,3Univerzitet u Prištini sa privremenim sedištem u Kosovskoj Mitrovici, Ekonomski fakultet, Katedra za \\ poslovnu ekonomiju, Kolašinska 156, 38220 Kosovska Mitrovica / \\ University of Priština (temporary in Kosovska Mitrovica), Faculty of Economics, Chair of Business, \\ Kolašinska 156, 38220 Kosovska Mitrovica
}

*Autor za prepisku / Corresponding author

Rad primljen / Received: 11.12.2020, Rad prihvaćen / Accepted: 08.05.2021.

\begin{abstract}
Sažetak: Šok koji je pandemija virusa COVID-19 izazvala u ekonomiji ističe da se brojni faktori na globalnom nivou mogu okarakterisati kao okidači ekonomske recesije, a među ovim faktorima posebna pažnja se danas posvećuje zdravlju ljudi. U okolnostima pandemije sektor upravljanja otpadom suočava se sa brojnim izazovima. To se posebno odnosi na one koji se bave prikupljanjem, razvrstavanjem, zbrinjavanjem i tretmanom medicinskog otpada. Medicinski otpad predstavlja potencijalni izvor infekcije, zato je neophodno da se bezbedno i na odgovarajući način sakupi, transportuje, preradi i privremeno ili konačno odloži. Količina medicinskog otpada (MO) se znatno povećala od početka pandemije, pri čemu ova kategorija obuhvata sve vrste otpada iz klinika, bolnica, laboratorija i ustanova koje posluju u okviru zdravstvenog sistema. Cilj rada je da se ukaže na značaj upravljanja medicinskim otpadom, jer on predstavlja veliki rizik po životnu sredinu, ali i po zdravlje osoba uključenih u sektor upravljanja otpadom. Autori u radu su nastojali da analiziraju stanje, izvrše komparaciju sa dostupnim istraživanjima koja su sprovedena u svetu i u Republici Srbiji u periodu pre početka i u toku same pandemije.
\end{abstract}

Ključne reči: cirkularna ekonomija, COVID-19, zaštita životne sredine, upravljanje otpadom, medicinski otpad (MO).

\begin{abstract}
The shock caused by the COVID-19 virus pandemic in the economy points out that numerous factors on a global level can be characterized as triggers of the economic recession, and among these factors, special attention is paid today to human health. In the circumstances of the pandemic, the waste management sector faces a number of challenges. This is especially true for those involved in the collection, sorting, disposal and treatment of medical waste. Medical waste is a potential source of infection, so it is necessary to safely and appropriately collect, transport, process and temporarily or permanently dispose of it. The amount of medical waste (MW) has increased significantly since the beginning of the pandemic, with this category covering all types of waste from clinics, hospitals, laboratories and institutions operating within the health system. The aim of this paper is to point out the importance of medical waste management, because it poses a great risk to the environment, but also to the health of persons involved in the waste management sector. The authors of the paper tried to analyze the situation, to compare it with the available research that was conducted in the world and in the Republic of Serbia in the period before the beginning and during the pandemic.
\end{abstract}

Keywords: circular economy, COVID-19, environmental protection, waste management, medical waste (MW).

\footnotetext{
${ }^{1}$ orcid.org/0000-0002-3972-4933, e-mail: andjelka.tripkovic@pr.ac.rs

${ }^{2}$ orcid.org/0000-0002-3582-8161, e-mail: Ijiljana.arsic@pr.ac.rs

${ }^{3}$ orcid.org/0000-0003-1804-9374, e-mail: sanja.dobricanin@pr.ac.rs
} 


\section{UVOD / INTRODUCTION}

Zdravstveni sistemi, na globalnom nivou, već godinu dana se suočavaju sa problemima koje izaziva pandemija COVID-19. Situacija je dovela do naglog povećanja broja pacijenata, što predstavlja rizik po zdravstvene radnike i zahteva upotrebu zaštitne opreme, detaljnu dezinfekciju, čime se stvara veća količina medicinskog otpada (MO), (Haque et al., 2020). Ako se medicinskim otpadom ne upravlja na adekvatan način može se pogoršati situacija u životnoj sredini. Budućnost sve više zahteva primenu savremenih metoda upravljanja otpadom (Vuković i dr., 2020).

Kao jedan od najvećih problema usled pandemije COVID-19 ističe se nedostatak radnika. Međutim, lokalne samouprave sa jedne strane, ali i javnokomunalna preduzeća, sa druge strane, suočavaju se sa ozbiljnim nedostatkom profesionalnog kadra u upravljanju medicinskim otpadom, imajući u vidu da se u ovoj turbulentnoj situaciji zahteva postojanje opreme kao što su kante, zaštitna sredstva i vozila. Stručnjaci ističu da se uz pomoć privatnog kapitala i fondova može modernizovati oprema za tretman opasnog otpada. Naime, upravljanje medicinskim otpadom može i mora postati sinonim za nacionalnu bezbednost kako bi se svetske privrede izborile sa krizom pandemije COVID-19 (Haque et al., 2020).

Neodgovarajuće uklanjanje medicinskog otpada je izvor zagađenja životne sredine, bilo kontaminacijom vodenih tokova i zemljišta ili zagađenjem vazduha putem emisija visoko toksičnih gasova. Samim tim, zbrinjavanje medicinskog otpada je veliki problem ne samo u slabo razvijenim državama, već i u onim razvijenim koje imaju značajne materijalne resurse, jer je cena njihovog zbrinjavanja veća.

Jedan od osnovnih prioriteta zakonodavstva u našoj zemlji je unapređenje sistema upravljanja infektivnim medicinskim otpadom kako bi se unapredilo zdravlje stanovnika pre svega, kao i kvalitet zdravstvenih usluga. Ministarstvo zdravlja Republike Srbije je prepoznalo da se procesu rešavanja problema upravljanja medicinskim otpadom mora pristupiti koncizno i temeljno.

Cilj rada jeste sagledavanje količine i dinamike stvaranja infektivnog medicinskog otpada za vreme pandemije COVID-19. Podaci o ukupnoj količini otpada koja se na godišnjem nivou proizvede u našoj državi jesu osnova za uspostavljanje adekvatnog sistema upravljanja otpadom. Agencija za zaštitu životne sredine i Republički zavod za statistiku izrađuju publikacije u određenim vremenskim intervalima, na osnovu čega se vrši dalja analiza i prezentovanje mogućih rešenja. Od početka pandemije količina infektivnog medicinskog otpada se znatno uvećala, pri čemu se oko 1,5 kilograma medicinskog otpada od 2019. godine generiše po bolničkom krevetu.

\section{UPRAVLJANJE OTPADOM KAO OSNOVA CIRKULARNE EKONOMIJE / \\ WASTE MANAGEMENT AS A BASIS OF CIRCULAR ECONOMY}

Kriza izazvna pandemijom COVID-19 je neistraženo područje, a ekonomske prognoze su varijabilne zbog neizvesnosti prouzrokovanih nepoznatim faktorima, kao što su zdravlje ljudi, promene ljudskog ponašanja, socijalna izolacija, napredak na pronalasku vakcine, finansijska kriza, pad BDP-a, i tome slično. U zavisnosti od ugla posmatranja, rezilijentnost se odnosi na otpornost, tj. sposobnost da se sistem suoči sa kriznom situacijom, da se prilagodi i vrati u ravnotežu. Takođe, rezilijentnost olakšava da se apsorbuje i ublaži šok, i svaki neočekivani i neželjeni događaj koji negativno i otežavajuće utiče na tranziciju, samoorganizaciju, održivost i rekonstrukciju infrastrukture (Munitlak Ivanović, Mitić, 2019).

Prvi zabeleženi slučaj oboljenja COVID-19 javio se krajem decembra 2019. godine u kineskoj pokrajini Hubej, u gradu Vuhan. Brzo širenje bolesti u zahvaćenom geografskom prostoru, po broju zaraženih/preminulih lica, za našu planetu predstavljao je veliki šok koji se ne pamti još od tridesetih godina prošlog veka. Kako postoji uverenje da su ekonomisti poznati kao veliki dogmatičari i kao neko ko se teško distancira od starih ideja, neminovno je morao za rešavanje ove krize u toku pandemije tražiti potpuno nova, inovativna rešenja. Da će koronavirus biti "zarazan" ekonomski, u istoj meri kao i medicinski, pokazuje i uticaj pandemije na međunarodnu trgovinu roba i usluga (Čavrak, 2020).

U Srbiji se prvi registrovani slučaj vezuje za 5 . mart 2020. godine, dok je 15. marta proglašeno vanredno stanje uz uvođenje brojnih mera. Srpska privreda je tokom 2020. godine ušla u fazu recesije. Od početka pandemije i uvođenja vanrednog stanja, čak 67.000 zaposlenih je radilo od kuće, dok je 186 proizvodnih kompanija obustavilo proizvodnju. Infrastruktura i transport su pretrpeli gubitke u iznosu od 110 miliona evra. Negativan uticaj pandemije COVID19 očekuje se kod $85 \%$ malih i srednjih preduzeća (MSP). Mala i srednja preduzeća (MSP) suočavaju se sa brojnim izazovima, uključujući nestabilan poslovni ekosistem, teškoće u naplati sopstvenih radova i usluga, visok nivo parafiskalnih taksi i teški i skupi pristup finansijama (Arsić i dr., 2020). 


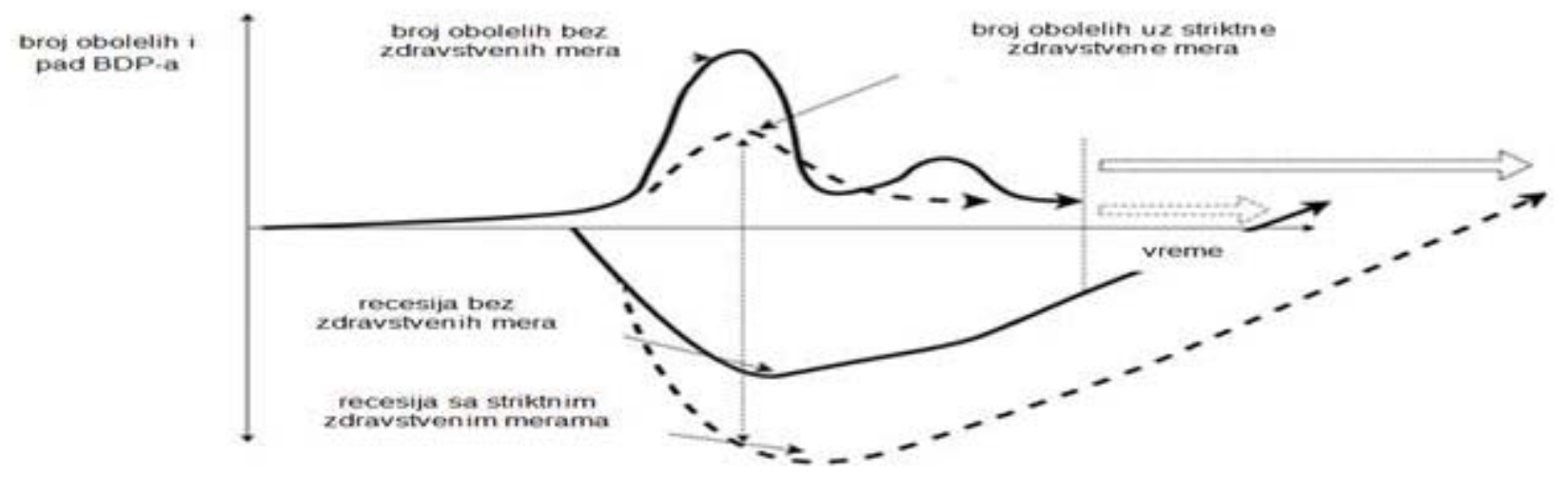

Slika 1 - Teorijska kriva pandemije COVID-19 i kriva recesije

Figure 1 - Theoretical curve of the COVID-19 pandemic and the recession curve Izvor / Source: Čavrak (2020)

U današnje vreme, svet karakterišu kompleksne vanredne situacije, a negativne posledice, koje one prouzrokuju, $u$ isto vreme obuhvataju različita područja života, pri čemu obim ljudskih i materijalnih gubitaka, koji nastaju usled vanrednih situacija, tokom poslednjih godina se značajno uvećao (Maksimović, 2012). Narušen odnos čoveka prema prirodnim resursima, kao posledica masovne proizvodnje i potrošnje, utiče na ponašanje savremenog čoveka, koji ne samo da koristi prirodu, nego je devastira do krajnjih granica (Munitlak Ivanović, Mitić, 2019). Ubrzo nakon pojave pandemije, svetska populacija je putem društvenih mreža i medija videla plaže u Hongkongu koje su bile prekrivene medicinskim rukavicama i maskama. S ekspanzijom pandemije sličan scenario je čekao i ostatak sveta, imajući u vidu da se otpad našao svuda oko nas, u prirodi, na ulicama, a domaćinstva nisu znala kako da postupaju s njim.

Upravljanje otpadom jeste jedan od najvažnijih postulata cirkularne ekonomije (CE), ali i bitna stavka koncepta održivog razvoja, u okviru kog se uzimaju u obzir brojni aspekti: ekološki, ekonomski, pravni, politički, tehnički i socijalni. Industrijske grane u kojima nastaju velike količine otpada trebalo bi da prepoznaju potencijal cirkularne ekonomije u rešavanju problema otpada i drugih pitanja iz domena zaštite životne sredine. Osnovni cilj cirkularne ekonomije jeste zaštita životne sredine od bilo kog vida degradacije i unapređenje socio-ekonomskih uslova datog društva (Vuković i dr., 2020).

Otpad je svaka materija ili predmet koji se odbacuje ili se namerava odbaciti. Osnovna klasifikacija otpada je na: komunalni otpad, komercijalni otpad i industrijski otpad. Globalno, postoji ozbiljan nedostatak pouzdanih podataka, od generisanja preko karakterizacije otpada, što otežava samo rešavanje problema njegovim upravljanjem.
Naša država „hronično zaostaje“ za zemljama Evrope u procesu upravljanja otpadom. Samo $80 \%$ komunalnog otpada se prikuplja (u odnosu na prosečnih $95 \%$ u zemljama centralne $\mathrm{i} i$ istočne Evrope) i odnosi uglavnom na nesanitarne zvanične deponije, dok ostatak završava na divljim deponijama i izvorištima vode (Papović i dr., 2019). Neka od pravila koja se moraju uzeti u obzir prilikom odlučivanja o opciji upravljanja otpadom jesu:

- opšti principi zaštite životne sredine predostrožnosti i održivosti;

- tehnička izvodljivost i ekonomska održivost;

- sveukupni uticaj na životnu sredinu, zdravlje ljudi, ekonomski i socijalni uticaj (Todorović, 2020).

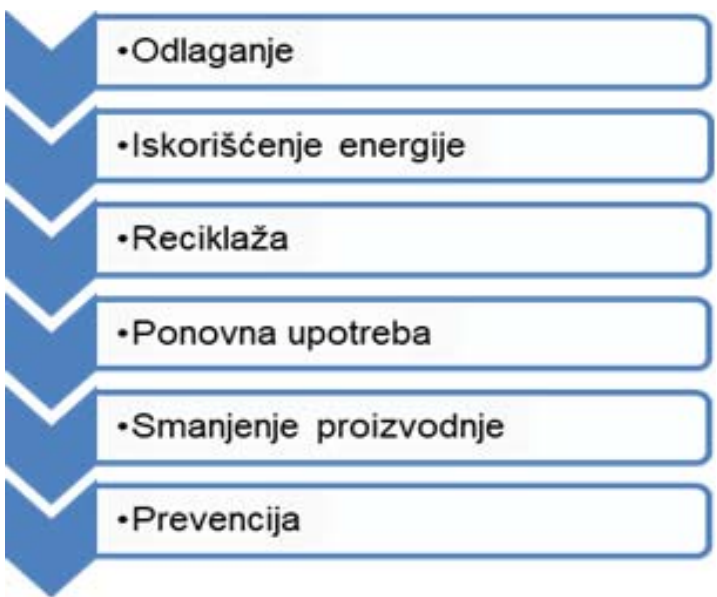

Slika 2 - Piramidalni prikaz hijerarhije u upravljanju otpadom

Figure 2 - A pyramidal view of the hierarchy in waste management

Izvor / Source: Todorović (2020)

U Zakonu o upravljanju otpadom se propisuje sledeće: „Kada se primenjuje hijerarhija otpada na 
koju se odnosu redosled hijerarhije upravljanja otpadom, preduzimaju se mere kojima se podstiču rešenja kojima se postiže najbolji ukupan rezultat za životnu sredinu što može zahtevati kod posebnih tokova otpada odstupanje od hijerarhije gde je to opravdano životnim ciklusom, uzimajući u obzir ukupne uticaje na nastajanje i upravljanje takvim otpadom“ (Zakon o upravljanju otpadom).

\section{MATERIJALI I METODE /} MATERIALS AND METHODS

Zdravstena zaštita kao bitnu delatnost ističe promociju, odnosno, unapređenje zdravlja, potom prevenciju, ili drugim rečima, sprečavanje bolesti, preventivno (rano) otkrivanje bolesti, te lečenje i uspešnu rehabilitaciju. Da bi se ovi ciljevi ostvarili, uz sveopšte dobro i korist, dolazi i do stvaranja velikih količina otpada, od kojih jedan deo pripada medicinskom otpadu (MO), (Majstorović, 2019). Medicinski otpad nastaje u zdravstvenim organizacijama, tj. u državnim i privatnim bolnicama, domovima zdravlja i Institutima za javno zdravlje, i to u nejednakim količinama zbog razlika između ovih zdravstvenih organizacija, počevši od broja kreveta, preko broja bolesnika, sve do načina njihovog zbrinjavanja. Klasifikacija MO u Evropskoj Uniji određena je Evropskim katalogom otpada (EU direktiva / Uputstvo saveta /2000/532/EC) koji je preuzet u naše propise. Za vreme trajanja pandemije u svetu Međunarodna asocijacija za upravljanje čvrstim otpadom dala je smernice kako da se države izbore sa problemima prekomerne količine otpada. Članica ove organizacije je i Asocijacija za upravljanje čvrstim otpadom Srbije (SeSWA), koja je dizajnirala posebna rešenja za upravljanje i odlaganje medicinskog otpada.

U toku istraživanja korišćene su induktivnodeduktivne metode i metode analize i sinteze, uz paralelno istraživanje i proučavanje inostranih iskustava u rešavanju problema otpada, pri čemu se akcenat stavlja na komparativne metode. Resorno ministarstvo u skladu sa Zakonom o upravljanju otpadom aktivno već godinama realizuje aktivnosti koje se odnose na impelemtaciju strategije upravljanja otpadom u Republici Srbiji. Podrška Zakonu jesu i programi Agencije za zaštitu životne sredine, a poslednja objavljena publikacija je iz 2019. godine, i to Upravljanje otpadom u Republici Srbiji u periodu 2011-2018, čime se prate proizvedene količine otpada u Republici Srbiji. Ministarstvo zdravlja naše države je pokrenulo projekat pod nazivom Tehnička podrška u upravljanju MO. Cilj je bio uspostaviti tzv. sistem upravljanja infektivnim medicinskim otpadom u zdravstvenim ustanovama metodom sterilizacije. Istovremeno, ovaj projekat edukuje zdravstvene radnike o zbrinjavanju infektivnog medicinskog otpada. Sam proces identifikacije i kategorizacije obuhvata nekoliko koraka:
- $\quad$ oštri predmeti (iskorišćene igle, skalpeli i dr.) treba da se odlažu u kontejnere sa UN kodom koji su neprobojni i koji ne propuštaju tečnost (ne cure) - žute kantice;

- otpad za tretman u autoklavima (gaza, špricevi, zavoji i sl.) treba upakovati u žute kese;

- $\quad$ komunalni otpad (neinfektivni papir, plastična ambalaža i dr.) odlaže se u crne kese određene za ovu vrstu otpada.

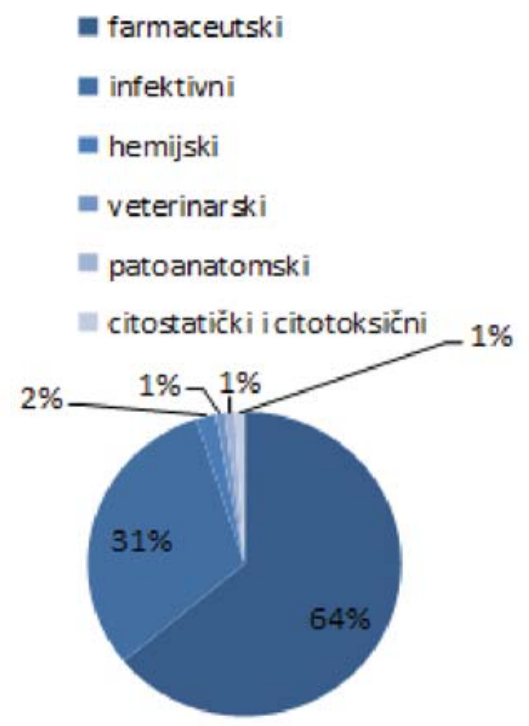

Slika 3 - Procentualni sastav generisanog medicinskog otpada

Figure 3. Percentage composition of generated medical waste

Izvor / Source: Šerović i dr. (2016)

Smatra se da je od početka pandemije količina medicinskog otpada utrostručena, a danas ova kategorija pored standardnog „materijala“ obuhvata i posteljine i plastične pribore za jelo iz bolnice. U Srbiji se prema nekim procenama na godišnjem nivou proizvede oko 5.000 tona infektivnog otpada. Što se tiče farmaceutskog otpada, u državnim ustanovama godišnje se proizvede 7.000 tona medicinskog otpada. Na ovu cifru se može dodati i oko 3.000 tona medicinskog otpada iz privatnog sektora. $U$ domaćinstvima se na godišnjem nivou proizvede oko 10 tona medicinskog otpada (Majstorović, 2019).

Proces odlaganja medicinskog otpada mora biti usmeren na dva nivoa, i to: na smanjenje negativnih posledica, s jedne strane, i na povećanje održivosti, s druge strane (Amin et al., 2013). Suština je da ustanove u kojima nastaje medicinski otpad tretiraju ovu kategoriju na ekonomičan način kako bi se vodilo računa o zdravlju ljudi i o životnoj sredini (Marceta, Nađ, 2018). Kada se radi o unapređenju zakonske regulative koja se odnosi na životnu sredinu, potrebno je pre svega raditi u onom segmentu 
koji se odnosi na stimulativno delovanje, odnosno, na sistem poreskih olakšica za one poslovne organizacije koje redovno investiraju u zaštitu živote sredine (Bogetić i dr., 2020).

Količina i sastav medicinskog otpada uglavnom zavise od mnogo faktora. Primera radi, istraživanja u italijanskim bolnicama su pokazala da tip sanitarne službe utiče na količinu generisanog medicinskog otpada (Šerović i dr., 2016). Na narednim tabelama i grafikonima prezentovani su rezultati upravljanja otpadom i upravljanja medicinskim otpadom u našoj državi i u svetu, za vremenske periode pre pandemije COVID-19 i nakon zvanično prvog zabeleženog slučaja.

Tabela 1 - Količina otpada, količina proizvedenog otpada po stanovniku, broj preduzeća koja generišu otpad i procentualni sastav otpada u Republici Srbiji, 2011-2019.

Table 1 - The amount of waste, the amount of waste produced per capita, the number of companies that generate waste and the percentage of waste in the Republic of Serbia, 2011-2019.

\begin{tabular}{|c|c|c|c|c|c|}
\hline Godina & Količina otpada & $\begin{array}{c}\text { Količina } \\
\text { proizvedenog } \\
\text { otpada po } \\
\text { stanovniku } \\
\text { (kg/stan/god) }\end{array}$ & $\begin{array}{c}\text { Broj preduzeća } \\
\text { koja generišu } \\
\text { otpad u } \\
\text { Republici Srbiji }\end{array}$ & $\begin{array}{c}\text { Količina } \\
\text { neopasnog } \\
\text { otpada (t) }\end{array}$ & $\begin{array}{c}\text { Količina } \\
\text { opasnog } \\
\text { otpada }(\mathrm{t})\end{array}$ \\
\hline 2011 & 7.337 .333 & 1,2 & 783 & 7.242 .191 & 95.142 \\
\hline 2012 & 10.601 .454 & 1,5 & 1.181 & 10.524 .139 & 77.315 \\
\hline 2013 & 9.881 .313 & 1,5 & 1.621 & 9.754 .383 & 126.930 \\
\hline 2014 & 7.451 .105 & 1,0 & 1.980 & 7.396 .241 & 54.864 \\
\hline 2015 & 9.354 .680 & 1,3 & 2.265 & 9.301 .212 & 53.468 \\
\hline 2016 & 9.197 .100 & 1,3 & 2.801 & 9.122 .782 & 74.319 \\
\hline 2017 & 11.476 .550 & 1,6 & 3.460 & 11.396 .548 & 80.002 \\
\hline 2018 & 11.613 .787 & 1,7 & 4.583 & 11.519 .280 & 94.507 \\
\hline 2019 & 11.976 .125 & 1,7 & 4.048 & 11.897 .712 & 78.413 \\
\hline
\end{tabular}

Izvor / Source: Agencija za zaštitu životne sredine (2020), str. 10

Kao što se može videti u tebeli, najveća količina stvorenog otpada bila je u 2019. godini, i to blizu 12 miliona tona. U poređenju sa 2011. godinom, došlo je do znatnog povećanja količine otpada nastale u postrojenjima za obradu otpada i komunalnog otpada. U 2018. i 2019. godini proizvedeno je po glavi stanovnika oko 1,7 kilograma otpada. Broj preduzeća koja izveštavaju o generisanju otpada se vremenom povećao, a u periodu od 2011. do 2019. godine čak pet puta. Udeo opasnog otpada je u posmatranom periodu iznosio od $0,6 \%$ do $1,3 \% \mathrm{u}$ odnosu na ukupnu količinu proizvedenog otpada.

Tabela 2 - Posledice COVIDA-19 na prekomernu upotrebu MO u svetu

Table 2 - Consequences of COVID-19 on overuse of MO in world

\begin{tabular}{|c|c|c|c|}
\hline Lokacija & Broj stanovnika & $\begin{array}{c}\text { Upotreba MO za vreme } \\
\text { pandemije po danu }\end{array}$ & $\begin{array}{c}\text { Upotreba MO za vreme } \\
\text { pandemije - 60 dana }\end{array}$ \\
\hline Manila & 14.000 .000 & $280 \mathrm{t} / \mathrm{d}$ & $16.800 \mathrm{t}$ \\
\hline Džakarta & 10.600 .000 & $212 \mathrm{t} / \mathrm{d}$ & $12.750 \mathrm{t}$ \\
\hline Kuala Lumpur & 7.700 .000 & $154 \mathrm{t} / \mathrm{d}$ & $12.600 \mathrm{t}$ \\
\hline Bangkok & 10.500 .000 & $210 \mathrm{t} / \mathrm{d}$ & $9.600 \mathrm{t}$ \\
\hline Hanoi & 8.000 .000 & $160 \mathrm{t} / \mathrm{d}$ & $\mathrm{s}$ \\
\hline
\end{tabular}

Izvor / Source: Asian Development Bank (ADB)

Prema zvaničnim podacima u svetu se upotreba medicinskog otpada uvećala $600 \%$, sa 40 tona na 240 tona dnevno. Ovo je jedan od razloga zašto se u kriznim situacijama mora voditi računa da medicinski otpad bude pravilno upakovan ali i obeležen uvek po propisu. Pre preuzimanja mora se dezinfikovati ambalaža u kojoj se nalazi pripremljeni otpad, a nakon toga i kontejner. Preporučuje se stalna dezinfekcija svih potencijalno kontaminiranih površina, međutim, ovo dovodi do većih troškova usled učes- 
talijih aktivnosti i većih mera zaštite. Na narednoj tabeli, Tabeli broj 3. predstavljeni su podaci o količinama proizvedenog medicinskog i veterinarskog otpada pre početka pandemije COVID-19 koji su dostavljeni od strane zdravstvenih ustanova u našoj državi.

Tabela 3 - Količina proizvedenog medicinskog i veterinarskog otpada u Srbiji za period 2011-2019.

Table 3 - Quantity of produced medical and veterinary waste in Serbia for the period 2011-2019.

\begin{tabular}{|c|c|c|c|c|c|c|c|c|c|}
\hline & 2011 & 2012 & 2013 & 2014 & 2015 & 2016 & 2017 & 2018 & 2019 \\
\hline $\begin{array}{c}\text { Količina } \\
\text { medicinskog i } \\
\text { veterinarskog } \\
\text { otpada (t/god) }\end{array}$ & 2342,51 & 2519,3 & 2455,3 & 2872,7 & 2822,0 & 2824,2 & 2997,57 & 3372,5 & 3281,8 \\
\hline
\end{tabular}

Izvor / Source: Agencija za zaštitu životne sredine (2020)

Tabela 4 - Posledice pandemije COVID-19 na zdravstveni sistem Republike Srbije

Table 4 - Consequences of the COVID-19 pandemic on the health system of the Republic of Serbia

\begin{tabular}{|c|c|c|c|c|c|c|c|}
\hline \multirow{2}{*}{$\begin{array}{l}\text { Ukupan } \\
\text { broj } \\
\text { bolničkih } \\
\text { kreveta } \\
\text { u Srbiji } \\
44.000\end{array}$} & \multirow{2}{*}{$\begin{array}{c}\text { Trenutna } \\
\text { iskoriš- } \\
\text { ćenost } \\
\text { kapaciteta }\end{array}$} & \multirow{2}{*}{$\begin{array}{c}\text { Količina } \\
\text { medicinskog } \\
\text { otpada po } \\
\text { bolničkom } \\
\text { krevetu na } \\
\text { dnevnom nivou } \\
(\mathrm{kg} / \mathrm{krev}) \\
1,5\end{array}$} & \multirow{2}{*}{ 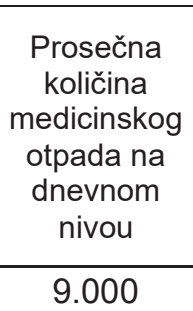 } & \multicolumn{2}{|c|}{ Ukupan broj zaraženih } & \multicolumn{2}{|c|}{ Ukupan broj preminulih } \\
\hline & & & & Svet & Srbija & Svet & Srbija \\
\hline \multicolumn{4}{|c|}{ Ukupno za vreme trajanja pandemije (MO): 4.927,5 } & 133.362 .992 & 629.388 & 2.891 .721 & 5.579 \\
\hline
\end{tabular}

Izvor / Source: Ministarstvo zdravlja, adaptirali autori.

\section{REZULTATI I DISKUSIJA / RESULTS AND DISCUSSION}

U zemljama u razvoju je početkom 90 -ih godina prošlog veka bilo 100-330 kilograma čvrstog otpada po glavi stanovnika, u EU je taj broj iznosio 414 kilograma, u Severnoj Americi - 720 kilograma. Iz tog razloga se industrijska društva često nazivaju „društvima otpada“ zbog velike količine otpada koja se stvara. U Engleskoj i Velsu, od 1997. godine do 1998. godine, od 27 miliona tona otpada koliko je proizvedeno, 90\% je otpad iz domaćinstva.

Zemlje koje upravljaju otpadom ostvaruju značajne ekološke i ekonomske koristi (Vuković i dr., 2020). U Srbiji se skoro sve vrste medicinskog otpada odlažu na komunalnim deponijama, koje uglavnom nisu uređene po evropskim i svetskim standardima, a na osnovu nekih procena se čak $20 \%$ medicinskog otpada skladišti u običnim kontejnerima. Prva ustanova u Srbiji koja je uvela proces upravljanja medicinskim otpadom je Gradski zavod za javno zdravlje - Beograd, koji sa uređajem marke Sintion navodi da infektivni otpad prolazi kroz proces sterilizacije, a zatim biva samleven.

Kineska provincija Hubej u kojoj je pandemija COVID-19 počela da se širi je interesantan primer uspeha uspostavljanja sistema da se medicinski i infektivni otpad tretira za 24h. Dnevno, kapacitet je porastao na 667,4 tona sa 180 tona, a Vuhan, epicentar pandemije, podigao je obim na 265.5 tona sa ranijih 50 tona dnevno. Kompanija Gient, koja je pre tri godine planirala da investira u izgradnju postrojenja u Srbiji, u Kini je za svega dve nedelje izgradila postrojenja za preradu MO kapaciteta 30 tona dnevno.

Ima primera lokalnih samouprava u našoj državi koje od početka pandemije pronalaze rešenja (u skladu s mogućnostima) i zalažu se za tretman i odlaganje medicinskog otpada. Opština Gornji Milanovac je uvela kontejnere za rukavice, maske, maramice na 30 mesta, u cilju bezbednog odlaganja od strane građana. U Čačku ljudi koji su u izolaciji dobijaju posebne kese za to. Gradska čistoća u Beogradu preuzima medicinski otpad nakon njegove sterilizacije parom, a on se potsle toga na deponiji u Vinči posebno tretira i odlaže.

Nemačka organizacija za međunarodnu saradnju, poznata kao GIZ, u saradnji sa Privrednom komorom Srbije dala je preporuke za odlaganje medicinskog otpada na deponije tokom pandemije COVID-19, neke od njih su sledeće: ukoliko ne postoji termički tretman medicinskog otpada, prva opcija podrazumeva odlaganje na sanitarnu deponiju; radnici na upravljanju otpadom i sakupljači otpada ne smeju doći u kontakt sa medicinskim otpadom tokom odlaganja; medicinski otpad ne bi smeo da se odlaže u okviru redovnih aktivnosti na deponiji; medicinski otpad mora biti istovaren što je 
bliže lokaciji za odlaganje; otpad mora biti odložen odmah nakon istovara kako ne bi predstavljao dodatni izvor zaraze za ljude, životinje, naročito ako se na deponiji nalaze i sakupljači otpada (GIZ, 2020).

\section{ZAKLJUČAK / CONCLUSION}

Pandemija COVID-19 je celom svetu donela zdravstvene, ekonomske i društvene teškoće. Upravljanje medicinskim otpadom predstavlja jedan od osnovnih indikatora zaštite životne sredine, ali istovremeno je i javni zdravstveni problem. Nesumnjivo je da je pandemija COVID-19 celom svetu donela brojne teškoće. Kako bi se naša planeta izborila sa globalnom krizom, potrebna je bolja organizacija upravljanja medicinskim otpadom, drugim rečima, potrebna je instalacija pogona za tretman opasnog otpada. Na ovaj način bi se obezbedio ekonomičan tretman generisanog medicinskog otpada koji bi bio u skladu sa održivim razvojem.

Paul Walker je rekao: „Znate, ono što je stvarno važno jeste da su ljudi oko vas srećni i zdravi. Sve ostalo je poput kapi kiše na pesku." Odgovornim ponašanjem pojedinaca, celokupne zajednice, i što je najvažnije, kontinuiranom edukacijom, mogla bi se obezbediti zaštita životne sredine i izgraditi sigurnost budućim generacijama.

\section{LITERATURA / REFERENCES}

[1] Agencija za zaštitu životne sredine, Upravljanje otpadom u Republici Srbiji 2011-2019, Beograd, 2020, pristupljeno 28. marta 2021. na https://www.ekologija.gov.rs/pretraga/upravljanje \%20otpadom\%20u\%20republici\%20srbiji.

[2] Amin, R., Gul, R., Mehrab, A. (2013). Hospital waste management; practices in different hospitals of Distt. Peshawar. Professional Med J 20(6): 988-994.

[3] Arsić, Lj., Premović, J., Milićević, Z., Đokić, N., Stošić, N. (2020), Afirmacija modela cirkularne ekonomije u malim i srednjim preduzećima, Ecologica, 27(100), str. 647-653.

[4] Asian Development Bank (ADB), Managing Infectious Medical Waste during the COVID-19 Pandemic, pristupljeno 30. marta 2020. na https://www.adb.org/sites/default/files/publication /578771/managing-medical-waste-covid19.pdf,

[5] Bogetić, S., Đorđević, D., Đorđević, Lj., Bakator, M. (2020), Analiza aspekata unapređenja životne sredine u procesu razvoja konkurentnosti, Ecologica, 27(97), str. 123-128.

[6] Čavrak, V. (2020), Makroekonomija krize COVID19 i kako pristupiti njenom rješavanju, EFZG WORKING PAPER SERIES, No 20-03.
[7] GIZ, Preporuke za odlaganje medicinskog otpada na deponije tokom pandemije virusa COVID-19, pristupljeno 28. marta 2021., na https://nemackasaradnja.rs/preporuke-zapravilno-odlaganje-medicinskog-otpada-tokompandemije-virusa-covid-19/.

[8] Haque, S., Uddin, S., Sayem, S., Mushfique, M. (2020), Coronavirus disease 2019 (COVID-19) induced waste scenario: A short overview, Environ Chem Eng, 9(1): 104660.

[9] Majstorović, V. N. (2019), Ekologija - upravljanje otpadom u stomatološkoj ordinaciji, Tehnika, 74 (4), str. 608-612.

[10] Maksimović, G. (2012), Institucionalni odgovor na vanredne situacije u Republici Srpskoj, Zbornik radova sa naučno-stručne konferencije Zaštita $i$ spasavanje - teorija i praksa, 67-81, Doboj.

[11] Marceta, M., Nađ, I. (2018), Effect of medical waste on health of population and environment in the Republic of Serbia, Zbornik radova Departmana za geografiju, turizam i hotelijerstvo, br. 472, str. 94-112.

[12] Ministarstvo zdravlja, Informacije o pandemiji COVID-19, pristupljeno 7. aprila 2021. na https://www.zdravlje.gov.rs/.

[13] Munitlak Ivanović, O., Mitić, P. (2019), Ekološka odgovornost u konceptu održivog razvoja i uticaj prirodnih katastrofa na rezilijentnost privrede, Ecologica, 26(96), str. 455-462.

[14] Papović, Z., Đorđević, S., Postolov, K. (2019), Investicije u zaštitu životne sredine i potrebe za izveštavanjem o zaštiti životne sredine kao deo društvenog poslovanja, Ecologica, 26(96), str. 577-582.

[15] Šerović, R. M., Jelić, I. V., Antonijević, D. Lj., Adžemović, M. R., Vujović, Z. R., Jovanović, V. S., Matić, B. I. (2016), Generisanje i upravljanje medicinskim otpadom u Srbiji - pregled, Tehnika, 71(3), str. 487-493.

[16] Todorović, M. (2020), Tretman otpada u Republici Srbiji, Napredak, 1(3), str. 131-144.

[17] Ugrinov, D., Stojanov, A. (2011), Upravljanje medicinskim otpadom, kao kategorijom javnog otpada, Zaštita materijala, 52(1), str. 55-59.

[18] Vuković, A., Riznić, D., Vuković, M. (2020), Cirkularna ekonomija u funkciji regeneracije prirodnih ekosistema, Ecologica, 27(98), str. 209-216.

[19] Vuković, M., Štrbac, N., Urošević, S., Vuković, A. (2020), Razvoj koncepta cirkularne ekonomije u skladu s principima održivog razvoja, Ecologica, 27(98), str. 187-193.

[20] Zakon o upravljanju otpadom (Službeni glasnik RS, br. 36/09, 88/10, 14/16 i 95/18 - dr. zakon). 